\title{
電波到来方向推定を用いた測位システム
}

\author{
小宮山 優*1 北 野 斉*1 桑 原 義 彦*2
}

\section{DOA-based Local Area Positioning System}

Masaru Komiyama*1, Hitoshi Kitano*1 and Yoshihiko Kuwahara*2

\begin{abstract}
We have developed a $\mathrm{DOA}^{\dagger}$-based local area positioning system for position measurement of autonomous sweeping robot "SuiPPi". This system can reduce the cost of the positioning system because it consists of a few components such as beacons, an array antenna and a signal processing unit. We have gotten the same accuracy as that of conventional TDOA system using wireless LAN. If beacons are placed at intervals of $20[\mathrm{~m}]$, we can provide a positioning information of the robot in the accuracy of about $2[\mathrm{~m}]$.
\end{abstract}

Key Words: DOA, Array Antenna, MUSIC, SuiPPi, Positioning

\section{1.はじめに}

ロボットが自律移動するためには，移動する環境の地図と，そ の環境の中で自分の位置を認識する手段が必要になる．筆者ら が開発した屋外清掃ロボット「SuiPPi」(Fig. 1) [1]は自身に 内蔵した地図情報とデッドレコニング情報を元に自律移動を行 う。また，さらにSuiPPi にはレーザレーダが搭載され，周囲の 壁やエリア内に設置されたリフレクタマークの情報を読み取り， 「SuiPPi」内部に保持された周囲の地図情報とのマッチングを 行うことで, デッドレコニング情報を随時補正して自己位置を 算出する，自己位置補正や障害物検出に使用するレーザレーダ の情報は, 検出距離 $8[\mathrm{~m}]$ 以内のデー夕を使用している。しか し，移動エリアが広く，壁やリフレクタの情報が得られない場 合にはデッドレコニングのみに依存することになるため, 起動 時などに自己位置を見失った場合や，デッドレコニングの誤差 が累積して自己位置が大きくずれた場合，隣り合うリフレク夕 マークの区別がつかずに誤った自己位置に補正してしまうとい う問題が考えられる.

このような問題に対して, Fig. 2 に挙げたような各種セン サ [2] を活用して自己位置を取得することが考えられる。自律移 動ロボットの移動エリアが屋外であれば，GPS ${ }^{\dagger \dagger}$ をいて自己位 置を検出することができる. 特に RTKGPS ${ }^{\dagger \dagger}[3]$ を用いれば, 数 $[\mathrm{cm}]$ の精度で自己位置検出が可能となる. しかし, 屋外でも 建物の近くや大きく張り出したテントのような庇の下では GPS

原稿受付 2006 年 7 月 24 日

*1松下電工株式会社生産技術研究所

$* 2$ 静岡大学工学部電気 $\cdot$ 電子工学科

${ }^{* 1}$ Matsushita Electric Works, Ltd.

${ }^{* 2}$ Faculty of Engineering, Shizuoka University

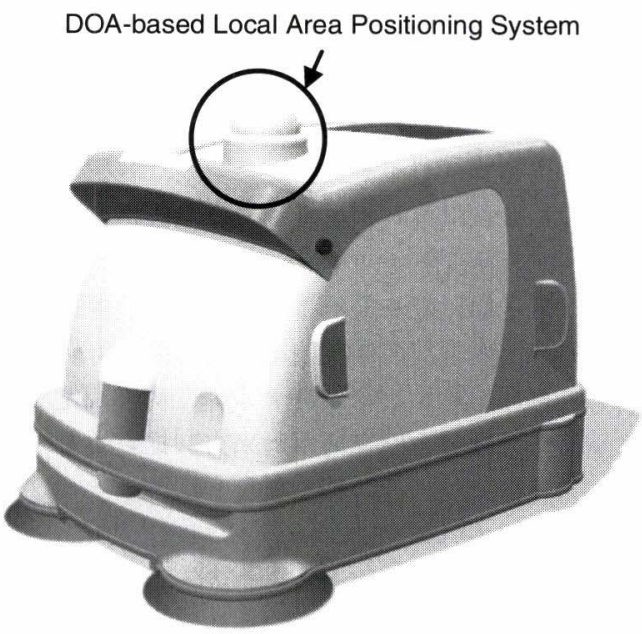

Fig. 1 Autonomous sweeping robot "SuiPPi"

による測位は困難であるが，掃除ロボットにとっては活用され るエリアである。また屋内で測位できないのは言うまでもない. この GPS の短所を補う測位センサとして, 無線 LAN 測位 [4], 超音波測位 [2], シュードライト [5] などがある。無線 LAN 測 位は, 無線 LAN クライアントからの電波を 4 箇所以上の無線 アクセスポイントで受信し, 電波の到達時間差 $\left(\mathrm{TDOA}^{\ddagger}\right)$ を 用いてクライアントの位置を計算する手法である. 商品も発売 されており実績もあるが，無線 LAN ネットワークの構築と位 置検出のためのサーバを設置する必要があるためシステムが大

\footnotetext{
${ }^{\dagger}$ Direction Of Arrival.

${ }^{\dagger \dagger}$ Global Positioning System.

${ }^{\dagger \dagger}$ Real Time Kinematics GPS

${ }^{\ddagger}$ Time Difference Of Arrival.
} 


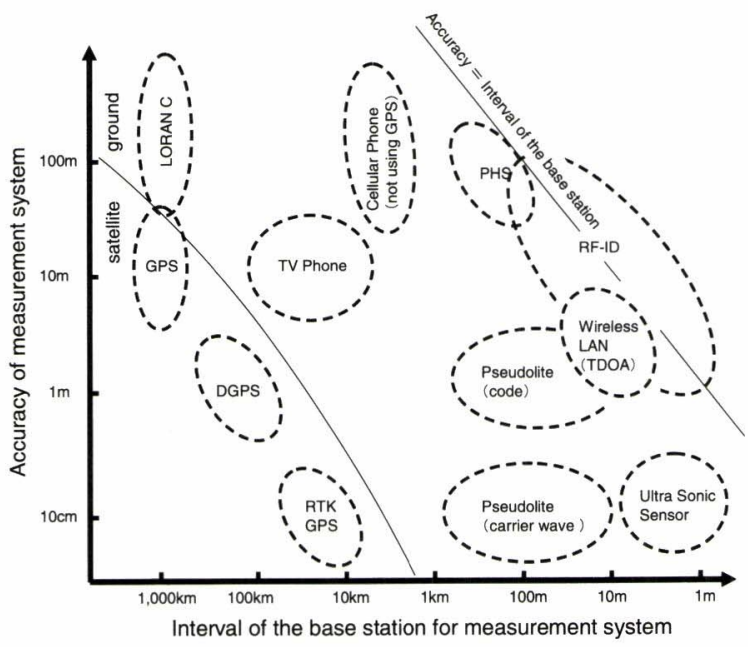

Fig. 2 Various measurement methods [2]

掛かりになる，超音波測位は，固定局からの超音波の伝播時間 を計測し，固定局との間の距離を求めて測位を行うものである. 精度は高いが超音波の到達距離が短いため, 固定局を数多く配 置する必要がある。シュードライトは, 地上に GPS 衛星と同 機能の擬似衛星を置くことで，GPS 衛星の配置や，障害物によ る可視衛星数の減少に伴う精度の劣化を防ぐ．高精度な測位が できるものの, GPS 衛星とシュードライト間での時刻同期が必 要なため, システムが大掛かりになる。また，実用化のために はマルチパスの影響, バイアス問題といった各種の技術課題も 残されている。これ以外にも電波到来方向推定を用いた測位技 術として総務省の電波監視システム “DEURAS” [6] が挙げられ るが, 複数の固定局で電波発信源からの電波の到来方向推定を 行い，それぞれの固定局の位置と電波発信源の方位を元にして 電波発信源の位置を見つけるシステムのため，固定局間のネッ トワーク構築や複数個の固定局用到来方向推定装置の設置が必 要となり, 大規模なシステム構成となる。

したがって，屋内外の掃除ロボットに搭載する測位センサと して，次の要件を満たす必要があると考えた。

(1) 屋内外の任意の場所で測位ができること

(2) システム構成がシンプルであること

（3）ロボット側端末一送信機間や送信機同士の, 配線や設定が 不要であること

(4) 隣り合うリフレクタマーク（最短で $6[\mathrm{~m}]$ 間隔）を誤認識 することのない測位精度（ $\pm 3[\mathrm{~m}]$ 未満）を得られること

そこで筆者らは，上記の要件を満たす新たな広域測位方式と して，測位エリアの周囲に設置した送信機から発信される電波 をアレイアンテナで受信し, MUSIC ${ }^{\dagger}$ 法 [7] で推定した電波到 来方位角を用いて後方交会法による測位を行う測位システムを 開発した。

本稿では，この測位センサの原理，構成および測位実験結果 について報告する。

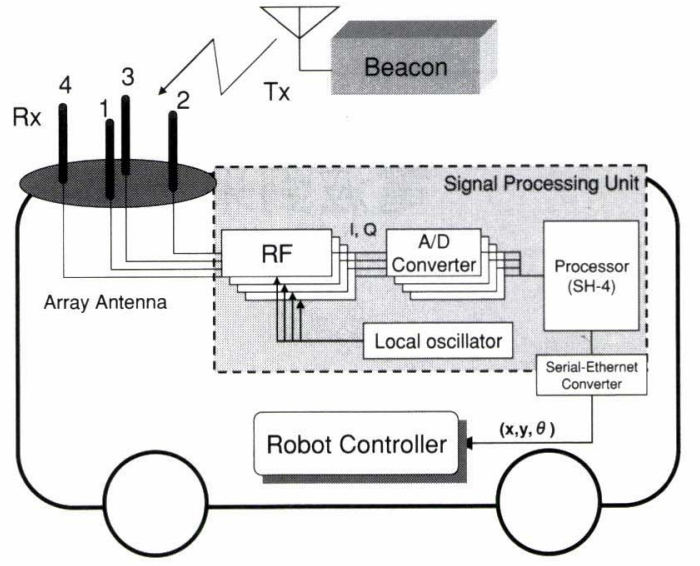

Fig. 3 Components of DOA-based local area positioning system

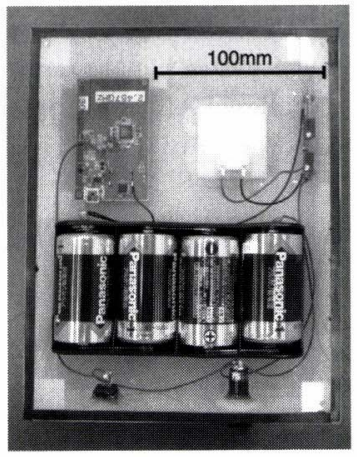

Fig. 4 Beacon

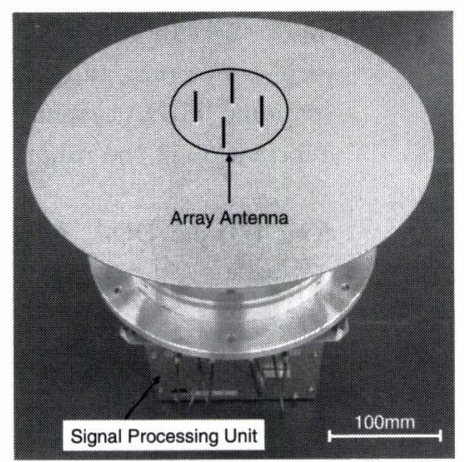

Fig. 5 Array antenna and signal processing unit

\section{2. 測位システム}

本測位システムは，既知点 $P_{1}, P_{2}, P_{3}$ に置かれた異なる周 波数の送信機から発信された電波を FDM 方式で見分け，それ ぞれの電波の到来方向推定結果 $\phi_{1}, \phi_{2}, \phi_{3}$ を用いて, ロボッ 卜の位置 $P$ と方位 $\theta$ を幾何的に算出する.

自律移動ロボットの移動には，位置情報に加えてロボットの 向きの情報も重要となる。従来の測位方式では位置情報のみを 算出するものがほとんどであるが，本測位システムでは位置情 報に加えてロボットの向き (姿勢) の情報も検出することがで きるため，ロボット用センサとして有用である.

本測位システムは，以下の要素から構成される (Fig. 3).

(1) $2.45[\mathrm{GHz}]$ 帯の CW 信号を発信する送信機（Fig. 4)

(2) 円形アレイ状に 4 素子が配置された $\lambda / 4$ 波長モノポール アンテナ (Fig. 5)

（3） 4 チャンネル受信機（RF）で周波数変換したアンテナのア レー応答デー夕を用いて到来方向推定と測位を行う信号処 理回路部 (Fig. 5)

（4）信号処理回路部と通信を行い，測位結果を取得するロボッ 卜内藏の演算器

Table 1 に本測位システムの主要諸元を示す. 
Table 1 The main parameter of DOA-based local area positioning system

\begin{tabular}{|c|c|}
\hline Frequency & $2.45[\mathrm{GHz}]$ \\
\hline ADC sampling rate & $10[\mathrm{Msample} / \mathrm{s}]$ \\
\hline ADC resolution & $12[\mathrm{bit}]$ \\
\hline Snapshots & 1000 \\
\hline Number of calibration data & 36 \\
& $10[\mathrm{deg}] \mathrm{step})$ \\
\hline MUSIC Spectrum search step & $1[\mathrm{deg}]$ \\
\hline
\end{tabular}

\section{3. 到来方向推定}

\section{1 アルゴリズム}

送信機から発信された電波の到来方向推定には, 従来用いら れてきたビームサーチ法よりも高精度な MUSIC 法を用いた。 MUSIC 法とは，未知角 $\phi$ から L 波の信号が入射した際，K 個のアンテナ素子でのアレー応答ベクトル $\vec{X}(t)$ の相関行列

$$
R_{x x}=E\left[\vec{X}(t) \vec{X}^{H}(t)\right]
$$

$(E[*]$ はアンサンブル平均, $H$ は複素共役転置) を求め, 相 関行列の固有ベクトル $\vec{e}_{i}(i=1,2, \cdots, K)$ と固有值 $\lambda_{i}(i=$ $1,2, \cdots, K), \phi$ 方向から入射する電波のアレーアンテナの応答 を表すステアリングベクトル $\vec{a}(\phi)$ を用いて，到来角 $\phi$ の関数 である MUSIC Spectrum $P_{M U}$ (Fig. 6)

$$
\begin{aligned}
P_{M U}(\phi) & =\frac{\vec{a}^{H}(\phi) \vec{a}(\phi)}{\vec{a}^{H}(\phi) E_{N} E_{N}^{H} \vec{a}(\phi)} \\
E_{N} & =\left[\vec{e}_{L+1}, \ldots, \vec{e}_{K}\right]
\end{aligned}
$$

を求める到来方向推定アルゴリズムである． $P_{M U}(\phi)$ がピーク を持つ $\phi$ が電波到来角 $\phi$ となる.

MUSIC 法は相関のない複数波が到来した場合でも複数波の 分離が可能なアルゴリズムだが，今回の SuiPPi の運用はオー プンスペースで行うため，マルチパスによる反射波や，送信機 以外の発信源はないものとして到来波数を 1 と仮定して到来方 向推定を行った。

\section{2 誤差評価実験}

電波暗室で受信アンテナを送信機に対して相対的に回転させ, MUSIC 法による到来方向推定誤差評価を行った．0３50 [deg] の $10[\mathrm{deg}]$ ステップのアレー応答ベクトル $\vec{X}(t)$ を補間してス テアリングベクトル $\vec{a}(\phi)$ として用い $[8]$, ステアリングベクト ル計測点の中間点である $5 \sim 355[\mathrm{deg}]$ の $10[\mathrm{deg}]$ ステップで 到来方向推定を行った．結果を Fig. 7 に示す．高速化のため, MUSIC Spectrum の角度分解能は 1 [deg] とした．到来方向 推定誤差は全周で $\pm 1[\mathrm{deg}]$ 以内であることが分かる．ただし， Fig. 7 の結果はステアリングベクトル計測時と同じ環境のため 良好な結果が得られているが，ロボットへの実装の影響・使用 環境によって電波状況が変化し，到来方向推定精度は悪化する と考えられる。

\section{4. 測位}

\section{1 アルゴリズム}

測位アルゴリズムには， 3 箇所の既知点 $P_{1}, P_{2}, P_{3}$ からの

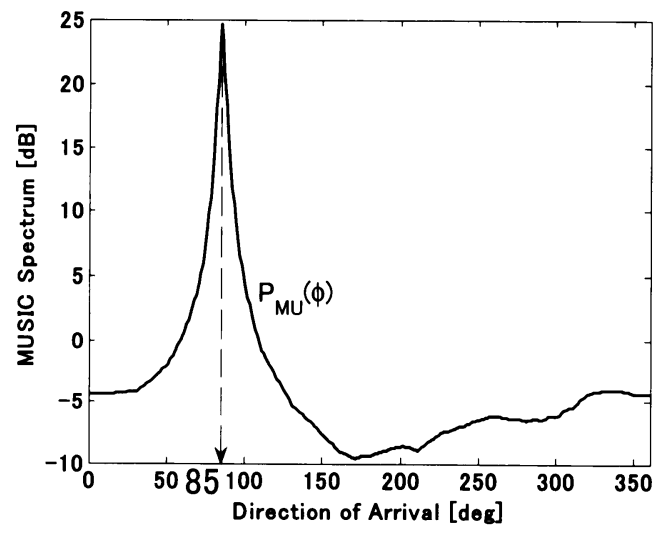

Fig. 6 MUSIC spectrum

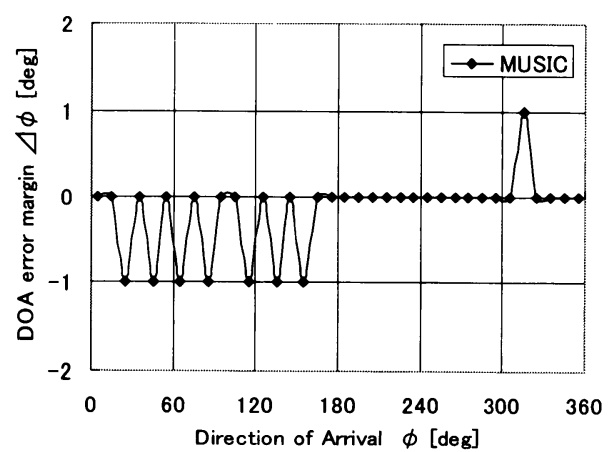

Fig. 7 DOA error margin by MUSIC algorithm

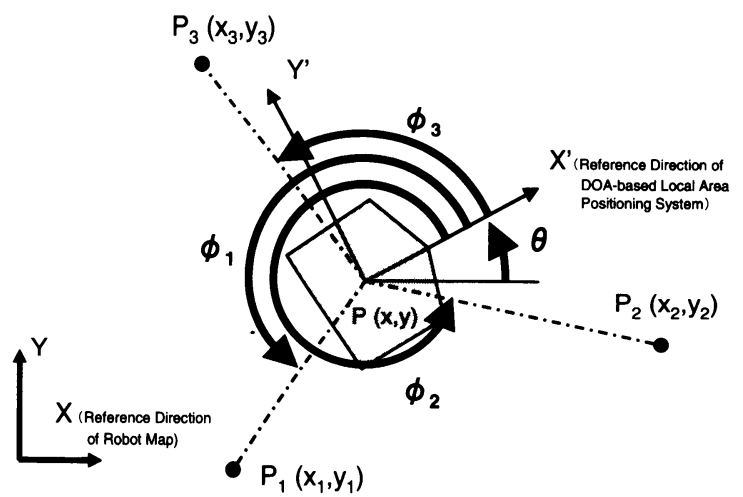

Fig. 8 Concept chart of DOA-based local area positioning system

電波到来角 $\left(\phi_{1}, \phi_{2}, \phi_{3}\right)$ を元に, 未知点の座標 $P(x, y)$, 絶対 方位 $\theta$ を求めるアルゴリズムを用いた（Fig. 8).

本アルゴリズムは, 測量学における後方交会法の一種である カッシーニの解法 (Fig. 9) を元にしている [9]. カッシーニの解 法では, 3 䇢所の既知点中の 2 点と末知点を通る円を二つ描き, 共通の既知点 $P_{2}$ から直径 $P_{2} P_{C}, P_{2} P_{D}$ を引くと, $P_{C} P P_{D}$ が一直線上に並び， $P_{C} P_{D} \perp P_{2} P$ となる幾何的拘束条件によ $\eta$, 未知点 $P(x, y)$ の座標を求める。 また, $P_{1}, P_{2}, P_{3}$ のう ち任意の送信機（既知点）の座標 $P_{i}\left(x_{i}, y_{i}\right)(i=1,2,3)$ と, 上 記の解法によって求められた受信アンテナの座標 $P$, 送信機 $P_{i}$ からの電波到来方向推定角 $\phi_{i}$ を用いて，送信機が置かれた絶 対座標系での受信アンテナの絶対方位 $\theta$ を求めることもできる. 


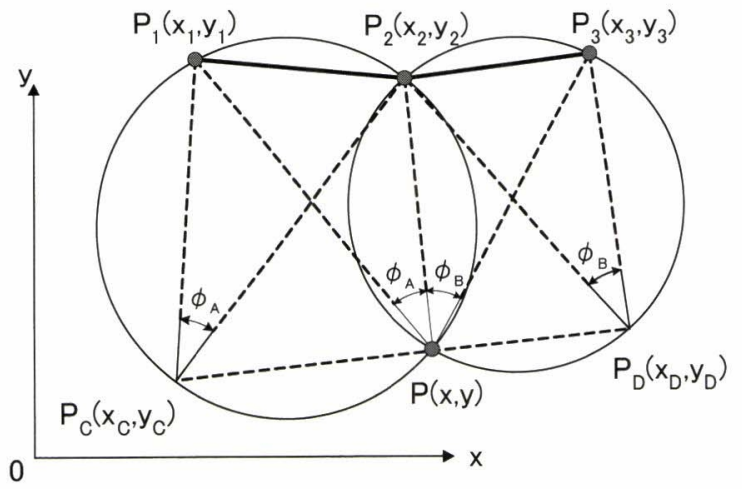

Fig. 9 Cassini's method

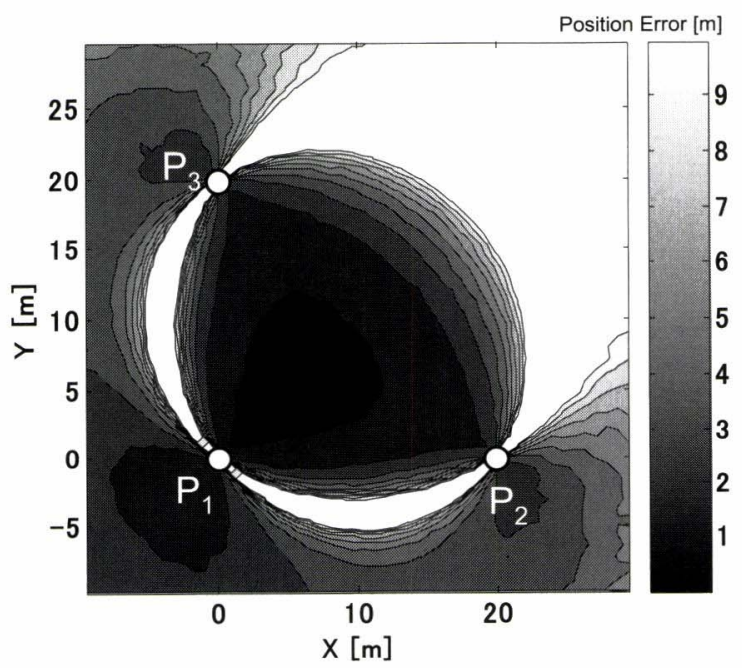

Fig. 10 Position measurement error margin $\Delta L$

$$
\begin{gathered}
x=\frac{\left(y_{2}-y_{c}\right)+\frac{x_{2}}{\tan \theta_{c d}}+x_{d} \times \tan \theta_{c d}}{\tan \theta_{c d}+\frac{1}{\tan \theta_{c d}}} \\
y=\frac{\left(x_{2}-x_{c}\right)+\frac{y_{c}}{\tan \theta_{c d}}+y_{2} \times \tan \theta_{c d}}{\tan \theta_{c d}+\frac{1}{\tan \theta_{c d}}} \\
\theta=\tan ^{-1} \frac{y_{i}-y}{x_{i}-x}-\phi_{i} \quad(i=1,2,3) \\
\left(\text { ここで, } \tan \theta_{c d}=\frac{y_{d}-y_{c}}{x_{d}-x_{c}}\right)
\end{gathered}
$$

4.2 精度評価シミュレーション

到来方向推定䛊差が測位精度に与える影響を評価するため, 以下のシミュレーションを行った。

(1) $P_{1}(0,0), P_{2}(20,0), P_{3}(0,20)$ に送信機を配置

(2) 受信アンテナの位置 $P(x, y)$, 向き $\theta$ を決め, $P$ の基準方 向から見た $P_{1}, P_{2}, P_{3}$ の方位 $\left(\phi_{1}, \phi_{2}, \phi_{3}\right)$ を算出

(3) 到来方向推定結果が誤差 $\left(\Delta \phi_{1}, \Delta \phi_{2}, \Delta \phi_{3}\right)$ を持つとして, $\left(\phi_{1}+\Delta \phi_{1}, \phi_{2}+\Delta \phi_{2}, \phi_{3}+\Delta \phi_{3}\right)$ を式（3）に代入し, 現 在位置 $P^{\prime}\left(x^{\prime}, y^{\prime}\right)$ を算出

(4) 測位誤差 $\Delta L=\sqrt{\left(x-x^{\prime}\right)^{2}+\left(y-y^{\prime}\right)^{2}}$ を算出

(5) 現在位置 $P(x, y)$ の変化に伴う測位䛊差 $\Delta L$ の変化を記録 到来角推定誤差 $\left(\Delta \phi_{1}, \Delta \phi_{2}, \Delta \phi_{3}\right)$ が平均 0 [deg] ·標準偏差

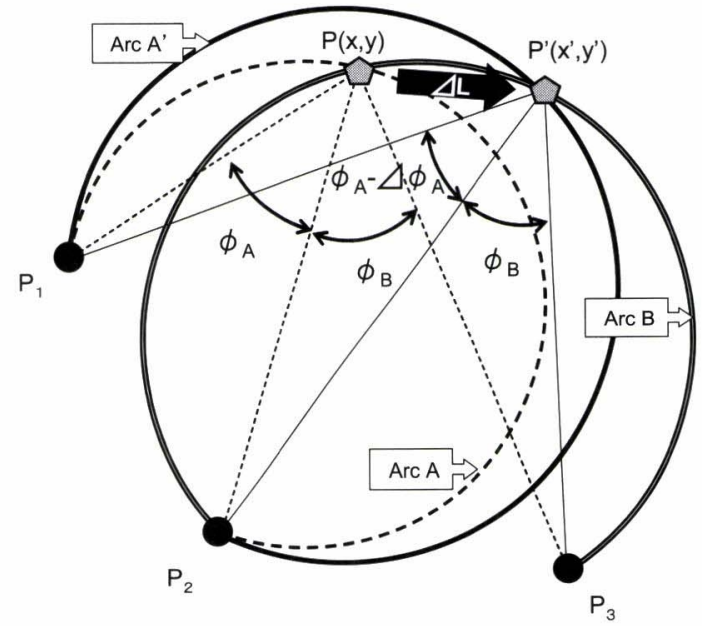

(a) Circular arc A and circular arc B are far

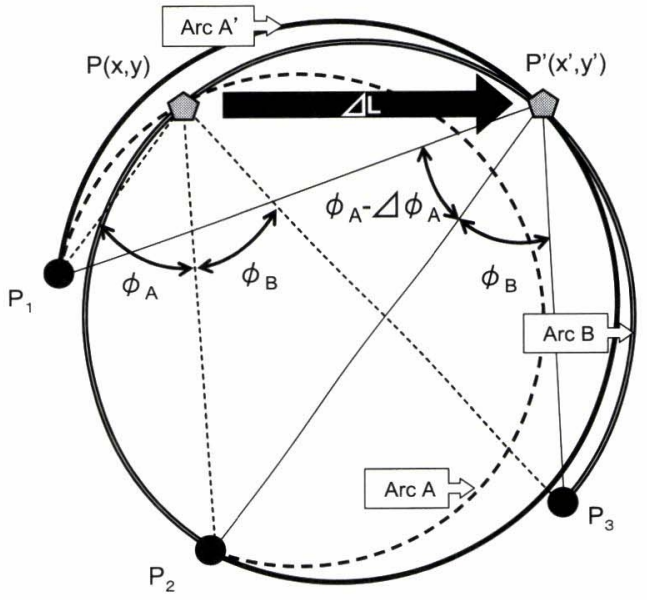

(b) Circular arc A and circular arc B are near

Fig. 11 Cause of generating postition measurement error mar$\operatorname{gin} \Delta L$

3 [deg] の正規分布を取るとしたときの計算結果を Fig. 10 に 示す。送信機 $P_{1}, P_{2}, P_{3}$ を含む円周上に受信アンテナ $P$ が 存在するときは, 測位誤差 $\Delta L$ が非常に大きくなる.これは Fig. 11 (a) を用いて以下のように説明できる. カッシーニの解 法では,

- $P_{1}, P_{2}$ を通り, $\phi_{A}=\phi_{2}-\phi_{1}$ を円周角とする円弧 $\mathrm{A}$

- $P_{2}, P_{3}$ を通り, $\phi_{B}=\phi_{3}-\phi_{2}$ を円周角とする円弧 $\mathrm{B}$

の交点が受信アンテナ位置 $P$ であるが, 到来方向推定誤差 $\Delta \phi$ が発生した結果, 円周角 $\phi_{A}$ が誤差を持ち $\phi_{A}-\Delta \phi_{A}$ となる と, 円弧 $\mathrm{A}$ の半径は変化して円弧 $\mathrm{A}^{\prime}$ となるため, 二つの円弧 の交点 $\mathrm{P}$ の位置は $\mathrm{P}^{\prime}$ となり, 測位誤差 $\Delta L$ が発生する.

二つの円弧がほぼ重なるときには, 小さな到来方向推定誤差 $\Delta \phi_{i}$ でも測位誤差 $\Delta L$ が大きくなる（Fig. 11 (b)）。 また，原 理上, 受信アンテナ $P$ が送信機 $P_{1}, P_{2}, P_{3}$ と同一円周上に あるときには二つの円弧が重なるため交点が発生せず，測位不 可能である。よって，本測位システムは送信機で囲まれるエリ アの内側で測位するのがよい.

Fig. 10 における，送信機よりも内側エリアでの測位位置誤差 


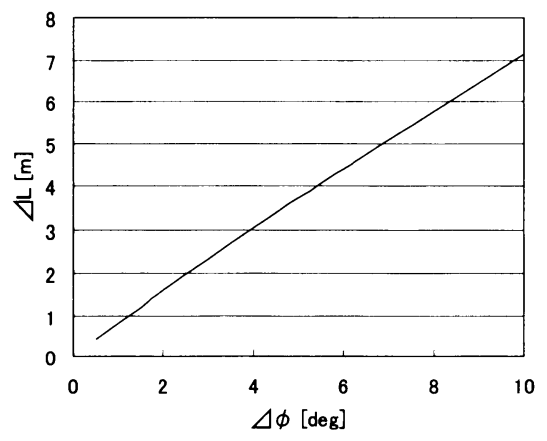

Fig. 12 Relation between $\Delta \phi$ and $\Delta L$

$\Delta L$ の RMS 平均值と, 到来角度誤差 $\Delta \phi$ との関係を Fig. 12 に示す. 測位位置誤差 $\Delta L$ を $2[\mathrm{~m}]$ 以下とするには, 約 $2.5[\mathrm{deg}]$ 以下の到来方向推定精度が必要となる。

\section{3 ロバスト性の高い後処理}

後方交会法による測位では, 三つの送信機からの電波到来推 定角 $\left(\phi_{1}, \phi_{2}, \phi_{3}\right)$ を元に受信アンテナの位置 $P(x, y)$ を測位す るが, 現実には電波は障害物による反射や散乱の影響によって 理想的な伝播状態とずれてしまう.そのため, まれに実際の送信 機方位とはまったく異なる方向に電波到来方向推定角 $\phi$ を得る ことがあり, Fig. 11 の 2 円の交点に相当する測位結果 $P(x, y)$ は誤差を持つ。このため本測位システムでは送信機を四つ置く ことによって測位結果に冗長性を持たせ, 異常な電波到来方向 推定角を含む測位結果を除去するアルゴリズムを搭載している. アルゴリズムは以下の通りである.

(1) 送信機が $P_{1}\left(x_{1}, y_{1}\right), P_{2}\left(x_{2}, y_{2}\right), P_{3}\left(x_{3}, y_{3}\right), P_{4}\left(x_{4}, y_{4}\right)$ の 4 䇢所に存在し, 到来方向推定角が $\phi_{1}, \phi_{2}, \phi_{3}, \phi_{4}$ のとき, 測位結果は以下の ${ }_{n} C_{3}=4$ 通り

$$
\begin{array}{lll}
P_{2}, P_{3}, P_{4}, \phi_{2}, \phi_{3}, \phi_{4} & \Longrightarrow & x_{234}, y_{234}, \theta_{234} \\
P_{1}, P_{3}, P_{4}, \phi_{1}, \phi_{3}, \phi_{4} & \Longrightarrow & x_{134}, y_{134}, \theta_{134} \\
P_{1}, P_{2}, P_{4}, \phi_{1}, \phi_{2}, \phi_{4} & \Longrightarrow & x_{124}, y_{124}, \theta_{124} \\
P_{1}, P_{2}, P_{3}, \phi_{1}, \phi_{2}, \phi_{3} & \Longrightarrow & x_{123}, y_{123}, \theta_{123}
\end{array}
$$

(2)

- 測位結果 : $P_{t}\left(x_{t}, y_{t}\right) \quad(t=123,124,134,234)$

- 送信機座標: $P_{i}\left(x_{i}, y_{i}\right) \quad(i=1,2,3,4)$ を用いると, 測位位置 $P_{t}$ から見た送信機 $P_{i}$ の方位は

$$
\theta_{t, i}=\tan ^{-1} \frac{y_{i}-y_{t}}{x_{i}-x_{t}}
$$

（3）正しい測位結果 $t$ では幾何的に

$$
\theta_{t, i}=\theta_{t}+\phi_{i}
$$

が成り立つため, $t$ に含まれるすべての $i(t=123$ なら $i=1,2,3)$ で式 (6) が成立すればその $t$ は正しい測位結 果とし, 少なくとも一つの $i$ で式 $(6)$ が不成立ならその $t$ は間違った測位結果として除去

上記の後処理による測位精度改善例を示す. $P(x, y)=$ $(5,16.5), \theta=90$ の位置・向きにアンテナを置いて測位を行 い, Table 2 (a) の到来方向推定結果を得た。測位結果は式 (3) より Table 2(b) となるため, 式 (4)〜 (6) を評価すると, $\phi_{2}$ の到来方向推定結果が異常であり, $t=134$ の組み合わせの
Table 2 Example of improving position measurement result (a) Positions and directions of beacons

\begin{tabular}{|c||c|c|c|}
\hline $\mathrm{i}$ & $\mathrm{x}$ & $\mathrm{y}$ & $\phi$ \\
\hline 1 & 0 & 0 & 163 \\
\hline 2 & 20 & 0 & 90 \\
\hline 3 & 20 & 19.8 & 275 \\
\hline 4 & 0 & 19.8 & 51 \\
\hline
\end{tabular}

(b) Position measurement result and judgement

\begin{tabular}{|c||c|c|c||c|}
\hline $\mathrm{t}$ & $\mathrm{x}$ & $\mathrm{y}$ & $\theta$ & Judge \\
\hline 234 & 15.3 & 43.5 & 186.1 & $\times$ \\
\hline 134 & 3.8 & 17.1 & 94.3 & $\bigcirc$ \\
\hline 124 & 6.2 & 6.7 & 244.2 & $\times$ \\
\hline 123 & 18.9 & -8.5 & 172.8 & $\times$ \\
\hline Ave & 11.1 & 14.7 & 174.4 & \multicolumn{1}{|c}{} \\
\cline { 1 - 2 } & \multicolumn{3}{|c}{} \\
\end{tabular}

みが正しい測位結果と判定される，四つの測位結果の単純平均 $(P(x, y)=(11.1,14.7), \theta=174.4)$ に比べ, 測位誤差が

$$
\begin{aligned}
& \Delta L: 6.3[\mathrm{~m}] \Rightarrow 1.3[\mathrm{~m}] \\
& \Delta \theta: 84.4[\mathrm{deg}] \Rightarrow 4.3[\mathrm{deg}]
\end{aligned}
$$

と改善したことが分かる.

\section{5. 測 位 実 験}

\section{1 条件}

以下の条件で, 本測位システムの測位精度評価実験を行った。

（1）異なる周波数を持つ送信機を 4 箇所に配置 $\left(P_{1} \sim P_{4}\right)$

(2) 4 個のうち 3 個の送信機からの電波到来方向推定角を元に 4 個の測位結果を求め, 4.3 節に示した最適化処理を実行

（3）測位精度評価実験を行った場所は以下の 3 箇所

(a) 屋内：10 [m] 法電波暗室（約 $18 \times 10\left[\mathrm{~m}^{2}\right]$ )

（b）屋外：愛・地球博（2005 年日本国際博覧会）会場西夕一 ミナル駐車場

（c）屋外：愛・地球博（2005 年日本国際博覧会）会場グロー バルループ（庇付き周回道路でマルチパス多い)

（4）受信アンテナの設置状態は以下の 2 種類

（a）電波的な影響の少ない木製台車に搭載した状態

（b）電源 ON 状態のロボット（SuiPPi）に搭載した状態

\section{2 結果}

駐車場・周回道路での測位実験の様子を Fig. 13 に, 電波暗 室・駐車場での測位実験結果を Fig. 14, Fig. 15 に示す。送 信機 $P_{1}, P_{2}, P_{3}, P_{4}$ は測位エリアの 4 隅に配置した。ロボッ 卜は本体のカバーや内部の機器類で電波の反射が起こり, 直接 波と反射波の重ねあわせで到来方向推定精度が低下する問題が あったため,

・カバー裏面への電波吸収体の貼付による反射波強度の低減

・アンテナ利得方向の変更による下方放射の低減 といった対策を行うことで，測位精度の改善を確認した。

各条件での測位実験の結果を Table 3 に示す．電波暗室での 木製台車を用いた実験・駐車場でのロボット搭載実験は日時を 変えて複数回行い, デー夕の再現性を確認した.

ここで, 送信機の設置間隔 $d[\mathrm{~m}]$ を送信機で囲まれる測位工 リア面積 $A\left[\mathrm{~m}^{2}\right]$ の平方根と定義し，送信機の設置間隔 $d$ に対す る位置誤差 $\Delta L$ (Fig. 16), 角度誤差 $\Delta \theta$ (Fig. 17) を条件ご とにプロットした，位置誤差 $\Delta L$ はアンテナの実装状況（木製 台車・ロボット）やマルチパス波の状況（電波暗室·駐車場・周 回道路）にかかわらず，送信機の設置間隔 $d$ と正の相関を持ち，

$$
\Delta L=0.09 \times d
$$


とほぼ近似できる，反射物や庇が設置されマルチパス波の多い 周回道路上での測位結果も式（7）上にプロットされることから， マルチパス環境下でも 4.3 節の最適化処理が機能していると考 えられる。電波到来角より測位を行う本方式では, 到来方向推 定角度誤差 $\Delta \phi$ が同じでも送信機の設置間隔 $d$ が倍になれば 位置誤差 $\Delta L$ も倍になる。これは幾何的に明らかである。本測 位システムは, アンテナ設置間隔 $d$ に対して約 $9 \%$ の誤差で測

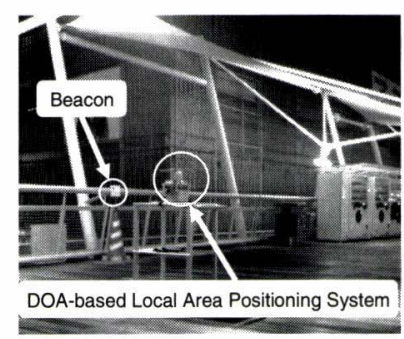

(a) On wooden cart in loop road

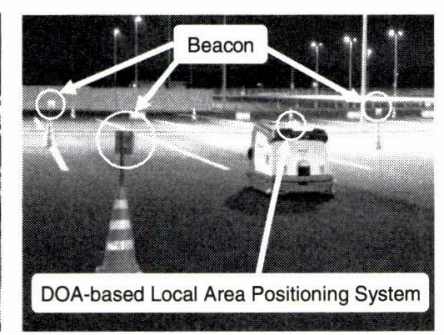

(b) On robot (SuiPPi) in parking lot

Fig. 13 Position measurement experiment

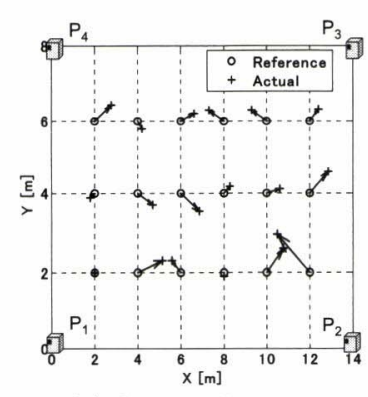

(a) On wooden cart

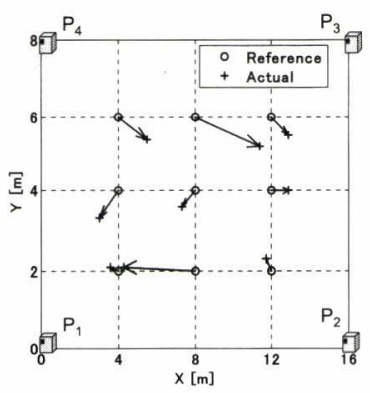

(b) On robot (SuiPPi)

Fig. 14 Result of position measurement experiment in anechoic chamber

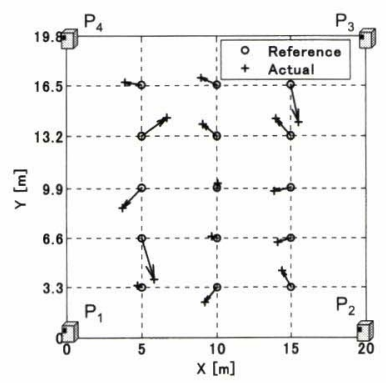

(a) On wooden cart

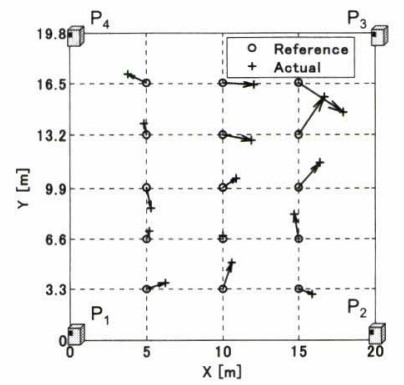

(b) On robot (SuiPPi)

Fig. 15 Result of position measurement experiment in parking lot

Table 3 Result of position measurement experiment

\begin{tabular}{|c|c|c|c|c|c|c|c|c|c|}
\hline & \multicolumn{3}{|c|}{ Indoor (In anechoic chamber) } & \multicolumn{3}{|c|}{ Outdoor (In parking lot) } & \multicolumn{3}{|c|}{ Outdoor (In loop road) } \\
\hline & $\mathrm{A}\left[\mathrm{m}^{2}\right]$ & $\Delta L[\mathrm{~m}]$ & $\Delta \theta[\mathrm{deg}]$ & $\mathrm{A}\left[\mathrm{m}^{2}\right]$ & $\Delta L[\mathrm{~m}]$ & $\Delta \theta[\mathrm{deg}]$ & $\mathrm{A}\left[\mathrm{m}^{2}\right]$ & $\Delta L[\mathrm{~m}]$ & $\Delta \theta[\operatorname{deg}]$ \\
\hline On wooden cart & $14 \times 8$ & $\begin{array}{l}0.8 \\
0.9\end{array}$ & $\begin{array}{l}2.3 \\
2.3\end{array}$ & $20 \times 19.8$ & 1.5 & 3.1 & $19.8 \times 16.5$ & 2.0 & 5.1 \\
\hline On robot & $16 \times 8$ & 1.9 & 6.9 & $\begin{array}{c}5 \times 3.3 \\
15 \times 9.9 \\
19.8 \times 10 \\
20 \times 19.8\end{array}$ & $\begin{array}{l}0.2 \\
0.7 \\
0.9 \\
1.8 \\
2.0\end{array}$ & $\begin{array}{l}5.6 \\
4.5 \\
7.2 \\
6.2 \\
6.2\end{array}$ & & & \\
\hline
\end{tabular}


Table 5 Feature of DOA-based local area positioning system

\begin{tabular}{|c|c|}
\hline Method & Using DOA \\
\hline Error Margin & $9 \%$ of beacon interval length \\
\hline Available Area & Indoor, Outdoor \\
\hline Advantage & Small \& simple system \\
\hline Fault & Larger error margin in larger area \\
\hline
\end{tabular}

\section{6.おわりに}

本稿では, 自律移動ロボットが広域環境で移動する際に自己 位置を検出するための電波到来方向推定法を用いた測位システ ムを提案した. そして, 本提案の電波到来方向推定法のアルゴ リズムと方向推定精度について述べた. 次に, 本測位システム の測位アルゴリズムの精度をシミュレーションにて評価し, よ りロバスト性の高いアルゴリズムを検討してその方法と改善結 果を述べた。ささらに, 本測位システムについて, 電波暗室での 測位から屋外の実環境での測位までを行ったときの測位結果を 示し, 測位エリアに対する測位精度について述べた。 その結果, 愛・地球博会場の屋外清掃において, $20[\mathrm{~m}]$ 間隔で送信機を設 置した際に，隣りあうリフレクタマークを䛊認識しない測位精 度（RMS 誤差 $2[\mathrm{~m}]$ ）を達成した.

本測位システムは Table 5 のような特徴を持つ. 屋外・屋内 ともに, ロボットの有無にかかわらず, 送信機設置間隔の 1 割 以下の誤差を達成しており, Fig. 2 の無線 LAN を用いたシス テムと同程度の測位エリアで, 同等以上の測位性能を実現して いる. 本測位システムは電波到来方向推定法を用いたことによ り，電波送信機間の同期や送受信アンテナ間の双方向通信など は必要なく, 電波送信機から非同期的に電波を送信するだけで 測位が可能となるため, システムとして非常にシンプルである. また, ネットワークの構築などが必要なく, 導入に関するコス トが安くなるメリットもある。

今後は, ロボット用測位センサとしてのさらなる測位精度向 上のために，実環境で教示を行うことで環境に対する適応性が
高いNeural-Network [10] [11] を用いた電波到来方向推定の高 精度化や，カーナビゲーションシステムなどにも用いられるカ ルマンフィルタ [12] を用いたノイズを含む時系列測位結果から のロボット自己位置推定の高精度化の検討を予定している.

謝 辞 本研究は, 独立行政法人新エネルギー・産業技術総 合開発機構（NEDO 技術開発機構）の「次世代ロボット実用化 プロジェクト (実用システム化推進事業)」によって採択された 「屋外用自律走行型掃除ロボットの開発」[13] の一部として行わ れました．関係者の方々に感謝いたします。

\section{参 考 文 献}

[1] 酒井龍雄 他: “自律走行型掃除ロボット SuiPPi”, ROBOMEC '06, 1A1-E03, 2006.

[2] 神谷泉：“測位技術の調査と IC タグ, UWB の測位への応用”, 国土 地理院時報, no.106, pp.31-36, 2005.

[ 3 ] 柳原, 初本: “RTK-GPS”, 情報処理学会誌, vol.43, no.8, pp.831835,2002

[4] 萩野敦 他：“無線 LAN 統合アクセスシステム一位置検出方式の検 討—”, マルチメディア, 分散, 協調とモバイルシンポジウム（DICOMO2003), pp.569-572, 2003.

[5] 須賀, 角田, 藤井, 福島, 齋藤：“エアポートシュードライト”, 情報 処理学会誌, vol.43, no.8, pp.853-859, 2002.

[6] 総務省: 電波監視システム, http://www.tele.soumu.go.jp/j/ monitoring/moni/type/deurasys/index.htm

[ 7 ] 菊間信良：アレーアンテナによる適応信号処理.pp.191-202, 科学技 術出版, 1998.

[8 ] 原六蔵, 山田寛喜, 山口芳雄：“校正用データセット数を軽減した反 復的アレー校正手法”，信学論 B, vol.J86-B, no.9, pp.1906-1913, 2003.

[ 9 ] 森忠次: 浿量学 1 基礎編 改訂版. pp.198-202, 丸善株式会社, 2001.

[10] 寺嶋亮太郎, 桑原義彦："RBF ニューラルネットワークを用いた到来 方向推定における多目的遺伝的アルゴリズムによる学習点の最適化”, 電子情報通信学会技術報告，pp.19-26, SPS2004, 2005 .

[11] 羽切健悟, 松本拓洋, 桑原義彦, 小宮山優, 北野斉：“屋内環境にお ける到来方向推定", 信学総大, B-1-27, 2006.

[12] 片山徹：応用カルマンフィル夕．朝倉書店, 1983.

[13] 独立行政法人新エネルギー・産業技術総合開発機構, 機械システム技 術開発部：「次世代ロボット実用化プロジェクト」第 1 回事後評価分 科会, 資料 5-1, 事業原簿, pp.III.2.1.1-1-16, 2007.

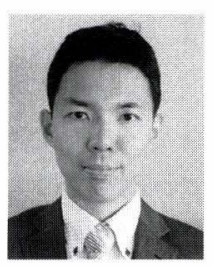

小宮山優（Masaru Komiyama）

1977 年 6 月 2 日生. 2002 年京都大学工学研究科 精密工学専攻卒業. 同年松下電工 (株) 入社. 以来, 自律移動ロボット, 測位センサ, ロボットセルなど の研究開発に従事. (日本ロボット学会正会員)

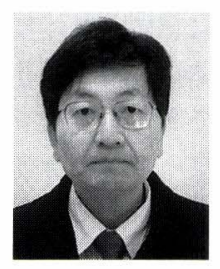

桑原義彦（Yoshihiko Kuwahara）

1956 年 2 月 19 日生. 1978 年慶應義塾大学工学部 電気工学科卒業. 同年日本電気 (株) 入社. 以来, フェーズドアレーアンテナ, アダプティブアンテナ, 電波伝搬，移動通信システム，ITS の研究開発に従 事. 1999 年静岡大学工学部助教授, 2006 年同教授. 工学博士. 1990 年防衛装備協会賞, 1998 年電波功 績賞受賞. 電子情報通信学会, IEEE, 太陽光発電衛星研究会会員.

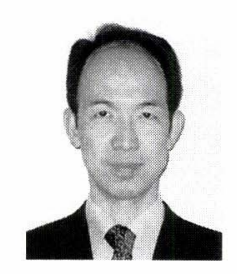

北野 斉 (Hitoshi Kitano)

1963 年 6 月 27 日生. 1986 年同志社大学工学部電 子工学科卒業. 同年松下電工 (株) 入社. 以来, リ ニアモータ, パラレルメカニズム, 全方向移動機構, 自律移動ロボット, 測位センサなどの研究開発に従 事. 1994 年高度自動化技術振興賞受賞. 2001 年日 本ロボット学会実用化技術賞受賞. 電気学会会員. 